\title{
Aging gene pathway of microRNAs $156 / 157$ and 172 is altered in juvenile and adult plants from in vitro propagated Prunus sp.
}

\author{
Adriana Bastías ${ }^{1}$, Rubén Almada ${ }^{2}$, Pamela Rojas ${ }^{1}$, José Manuel Donoso, \\ Patricio Hinrichsen ${ }^{3}$, and Boris Sagredo ${ }^{1}$ \\ ${ }^{1}$ Instituto de Investigaciones Agropecuarias, INIA-Rayentué, Avenida Salamanca s/n, Sector Los \\ Choapinos, Rengo, Chile. \\ ${ }^{2}$ Centro de Estudios Avanzados en Fruticultura (CEAF), Avenida Salamanca s/n, Sector Los Choapinos, \\ Rengo, Chile. \\ ${ }^{3}$ Instituto de Investigaciones Agropecuarias, INIA-La Platina, Santa Rosa 11610, La Pintana, Santiago, \\ Chile.
}

\begin{abstract}
A. Bastías, R. Almada, P. Rojas, J.M. Donoso, P. Hinrichsen, and B. Sagredo. 2016. Aging gene pathway of microRNAs 156/157 and 172 is altered in juvenile and adult plants from in vitro propagated Prunus sp. Cien. Inv. Agr. 43(3):429-441. In vitro culture is a very popular technique to mass propagate valuable plant genotypes, including Prunus sp. cultivars. Plants that undergo tissue culture processes often change their morphology and behavior due to the "rejuvenation" caused by the plant growth regulators included in the medium. To evaluate the effects of rejuvenation by tissue culture in Prunus sp., the expression patterns of the aging gene pathway described in plant models, which include the highly conserved microRNA (miRNA or miR) 156/157 and 172 families and several of their respective target genes, were analyzed in distinct Prunus sp. genotypes at different phases of maturity, including true seedling and tissue culture micropropagated plants. In genotypes from true seedling plants, the expression of miR156 and miR157 was higher in the leaves of juvenile plants (one year old) than in those of adult plants (six year old). The opposite pattern was observed with miRNA172 expression. Our results suggest that the aging gene pathway is relatively conserved in Prunus and likely plays a key role in vegetative phase change. However, Prunus sp. plants that were rejuvenated and propagated by in vitro methods showed more erratic behavior for miR156 and miR157 and their target genes, suggesting that tissue culture alters the normal control of the aging pathway.
\end{abstract}

Key words: development, in vitro culture, phase change, rejuvenation.

\section{Introduction}

Plants undergo several changes during their life cycle, including changes in vegetative morphology, reproductive potential, flowering, seed set

Received June 7, 2016. Accepted September 29, 2016. Corresponding author: bsagredo@inia.cl and senescence. The shoot of a seedling begins its development in the juvenile phase, which is characterized by a variety of morphological traits including leaf shape and size and the insensitivity of the shoots to floral stimulus (Bergonzi and Albani, 2011). The transition to the adult phase, termed vegetative phase change, is marked by an increase in reproductive potential. Flower induc- 
tion begins during the adult phase and is regulated by endogenous signals as well as environmental factors (Bergonzi and Albani, 2011).

Prunus is a commercially important tree genus that contains species with different juvenility periods where the juvenile-to-adult transition is an economically important trait because it directly affects the length of breeding cycles as well as the precocity of orchards. A very popular mass propagation technique for varieties of Prunus rootstocks is tissue culture (Alanagh et al., 2014). Because not all the genotypes respond satisfactorily to similar in vitro propagation methods (even within the same species), there is ongoing extensive research to develop specific protocols for valuable genotypes (Alanagh et al., 2014).

In vitro propagation of woody trees such as Prunus sp. has significant effects on the expression of juvenile or adult traits. A successful tissue culture protocol must reverse the tendency of aging of an adult plant by a process of rejuvenation (von Aderkas and Bonga, 2000). The reduced rooting ability of an adult plant is the main trait that has to be reversed, which is often achieved by the tissue culture of adult buds (Wendling et al., 2014). However, it is still not clear whether these artificial methods generate true juvenile plants with reduced ontogenetic age or if the methods just produce plants with reduced physiological age (reinvigorated) by temporarily removing environmental and physiological constraints to growth (Wendling et al., 2014).

At the molecular level, the microRNAs (miRNAs or miRs) $156 / 157$ and 172 in angiosperms play a critical role in the regulation of juvenile-to-adult vegetative phase change and flowering (Wu et al., 2009). This aging pathway seems to be conserved in fruit tree species, such as those belonging to the Prunus genus of the Rosaceae family (Xu et al., 2015).

The miR156, probably together with the related miR157, regulates a family of transcription factors called Squamosa Promoter Binding Protein-Like (SPL) (Bergonzi and Albani, 2011). SPL is a diverse family and contains an SBP (Squamosa binding protein) domain with two zinc-binding sites as well as a nuclear localization signal. This protein family is plant specific and is encoded by a large gene family (Cardon et al., 1999). For instance, 16 and 15 SPL genes have been described in $A$. thaliana and $P$. mume Siebold \& Zucc., respectively (Cardon et al., 1999; Xu et al., 2015).

In $A$. thaliana, miR156 regulates a subset of members of the SPL family post-transcriptionally and translationally (Bergonzi and Albani, 2011). During the juvenile phase, miR156 expression is high in leaves, whereas expression is lower in leaves produced during the adult phase in species such as A. thaliana (Wu et al., 2009) and some trees such as Populus $\times$ canadensis Moench, Acacia confuse Merr. and Eucalyptus globulus Labill (Wang et al., 2011). While expression of SPLs genes is low in the juvenile phase, it increases in the adult phase (Wang et al., 2009). Plants with over-expression of miR156 flower late, whereas plants with inhibited miR156 activity flower early (Wang et al., 2009). Another miR involved in vegetative phase change is miR172, which is expressed in an opposite manner to miR156 (Aukerman and Sakai, 2003; Wu et al., 2009). The over-expression of miR172 promotes adult leaf traits and flowering (Jung et al., 2011). In A. thaliana, the targets of miR172 are the following six floral repressors: Apetala 2 ( $A P 2)$ and a group of AP2-like genes including Target of Eat (TOE) 1, 2, and 3, Schlafmutze (SMZ), and Schnarchzapfen (SNZ) (Aukerman and Sakai, 2003).

To increase our knowledge about the molecular components and the networks that regulate juvenileto-adult vegetative and reproductive transitions in Prunus sp. and the effects of rejuvenation by tissue culture in Prunus sp. transitions, we characterized the expression patterns of mature miR156/157 and miR172 and their putative target genes in leaves of Prunus of several genotypes of different ages and developmental stages and compared plants 
from true seeds with plants micropropagated by in vitro tissue culture.

\section{Materials and methods}

\section{Plant material}

Fully expanded leaf samples from four P. avium L. genotypes (C14H3P1, C14H8P1, C15H14P20 and C15H16P3) were obtained in the summer of 2016 from the INIA Cherry Breeding Program, Rengo, Chile. Samples were taken from among the central leaves of each tree. These genotypes are progeny of cv. 'Emperor Francis' as the mother in an open in-field pollination system. The younger genotypes, C15H14P20 and C15H16P3, were planted in 2015, while the older ones, $\mathrm{C} 14 \mathrm{H} 3 \mathrm{P} 1$ and $\mathrm{C} 14 \mathrm{H} 8 \mathrm{P} 1$, were planted in 2009. The latter genotypes bloomed for the first time during the 2012 season. Samples were collected, immediately frozen in liquid nitrogen, and then stored at $-80{ }^{\circ} \mathrm{C}$ until RNA extraction and gene expression analyses.

Pathogen-free clonally in vitro propagated plants of Prunus hybrid genotypes were donated by Agromillora Sur nurseries (Chile). Plant material included the almond $\times$ peach hybrid (P. amygdalus (L.) Batsch $\times$ P. persica L.) 'Garnem' (G x N 15), the plum hybrid 'Mariana 2624' ( $P$. cerasifera Ehrh. $\times$ P. munsoniana W. Wight \& Hedrick), the sweet and sour cherry hybrid ( $P$. avium $\times$ $P$. pseudocerasus Lindl.) 'Colt' and the sweet cherry Mazzard F12/1 (P. avium). Plants were transplanted in $2 \mathrm{~L}$ plastic pots with a mixture of sand:vermiculite:perlite (1:1:1) as substrate and kept in the field under a shade net (Raschel sun-shading net with 50\% light transmittance) at the Instituto de Investigaciones Agropecuarias (INIA) Rayentué, Rengo, Chile (S34¹9'16.8', W70 50 '02.2”). Plants were watered three times a week with tap water and fertilized every two weeks with 1 g pot $^{-1}$ with N:P:K (25:10:10) (Ultrasol ${ }^{\mathrm{TM}}$, Soquimich, Chile). The above procedure was repeated during three growing seasons until obtaining one-, two- and three-year-old plants. Central leaves from each tree of 'Garnem','Mariana2624', 'Colt' and 'Mazzard F12/1' genotypes were collected, immediately frozen in liquid nitrogen, and stored at $-80{ }^{\circ} \mathrm{C}$ until RNA extraction and gene expression analyses. Three-year-old plants of the 'Garnem' and 'Mariana 2624' genotypes flowered, but 'Colt' and 'Mazzard F12/1' did not. The main characteristics of the plant genotypes used in this study are summarized in the Table 1.

\section{Gene expression analysis}

To analyze the expression of mature miR156 and miR172, miRNAs were isolated with the mirVana $^{\mathrm{TM}}$ miRNA Isolation Kit according to the manufacturer's instructions (Ambion, Inc., Applied Biosystems, USA). TaqMan®MicroRNA Assays (Applied Biosystems, Life Technologies, USA) of $A$. thaliana were then used to assess miRNA expression. The probes were designed to detect and accurately quantify mature miRNAs 156, 157 and 172. Five ng of total RNA was used to detect miRNAs. The qPCR reactions included $1 \mu \mathrm{L}$ of TaqMan ${ }^{\circledR}$ Small RNA Assay (20X), $1.33 \mu \mathrm{L}$ of product from reverse transcription (RT) reaction, $10 \mu \mathrm{L}$ of TaqMan ${ }^{\circledR}$ Universal PCR Master Mix II (2X), and nuclease-free water to reach a final volume of $20 \mu \mathrm{L}$. TaqMan ${ }^{\circledR}$ Small RNA Control (Applied Biosystems, Life technologies, US) of the sno41Y probe was used as predesigned assays for small, non-coding RNAs unrelated to miRNAs to normalize differences derived from RNA sample preparation.

Three technical replicates for each biological replicate $(n=3)$ were performed in all the gene expression analyses in this study. In the case of vegetative propagated clones, the biological replicates consisted of different plants, but for seedling plants, the biological replicates were different leaves from the same plant.

To analyze the expression of SPL and TOE genes, total RNA was obtained from leaves of three plants according to Chang et al. (1993). Total RNA 
Table 1. Summary of plants used in this study.

\begin{tabular}{|c|c|c|c|c|c|}
\hline Name & Scientific name & Type & Propagation/origin & Age (year) & Flowered \\
\hline C14H3P1 & P. avium & Breeding clone & Seed & Six & Yes \\
\hline C14H8P1 & P. avium & Breeding clone & Seed & Six & Yes \\
\hline $\mathrm{C} 15 \mathrm{H} 14 \mathrm{P} 20$ & P. avium & Breeding clone & Seed & One & Not \\
\hline $\mathrm{C} 15 \mathrm{H} 16 \mathrm{P} 3$ & P. avium & Breeding clone & Seed & One & Not \\
\hline 'Garnem' & $\begin{array}{c}\text { P. amygdalus } \times P \text {. } \\
\text { persica }\end{array}$ & Rootstock cultivar & In vitro culture & $\begin{array}{c}\text { One } \\
\text { two } \\
\text { three }\end{array}$ & $\begin{array}{l}\text { Not } \\
\text { Not } \\
\text { Yes }\end{array}$ \\
\hline 'Mariana 2624' & $\begin{array}{l}\text { P. cerasifera } \times \mathrm{P} \text {. } \\
\text { munsoniana }\end{array}$ & Rootstock cultivar & In vitro culture & $\begin{array}{l}\text { One } \\
\text { Two } \\
\text { three }\end{array}$ & $\begin{array}{l}\text { Not } \\
\text { Not } \\
\text { Yes }\end{array}$ \\
\hline 'Colt' & $\begin{array}{c}\text { P. avium } \times P . \\
\text { pseudocerasus }\end{array}$ & Rootstock cultivar & In vitro culture & $\begin{array}{l}\text { One } \\
\text { Two } \\
\text { three }\end{array}$ & $\begin{array}{l}\text { Not } \\
\text { Not } \\
\text { Not }\end{array}$ \\
\hline 'Mazzard F12/1' & P. avium & Rootstock cultivar & In vitro culture & $\begin{array}{l}\text { One } \\
\text { Two } \\
\text { three }\end{array}$ & $\begin{array}{l}\text { Not } \\
\text { Not } \\
\text { Not }\end{array}$ \\
\hline
\end{tabular}

integrity and purity was verified by formaldehyde agarose gel electrophoresis and OD260/280 absorbance ratio, respectively. DNase treatment of total RNA and first-strand cDNA synthesis was carried out with $1 \mu \mathrm{g}$ of total RNA for each sample using oligo (dT) primers according to the manufacturer's instructions (Invitrogen, USA). The quantitative real-time PCR reactions were performed with Brilliant SYBR Green Master Mix (Stratagene, USA) according to the manufacturer's instructions. The quantitative real-time PCR reactions included $2 \mu \mathrm{L}$ Master Mix, $0.5 \mu \mathrm{L}$ $250 \mathrm{nM}$ of each primer, $1 \mu \mathrm{L}$ diluted cDNA, and nuclease-free water to reach a final volume of 20 $\mu \mathrm{L}$. Controls (without cDNA and RNA without RT) were included in each run. Amplification was followed by melting curve analysis. Expression was normalized against the $P$. persica TEF2 gene (translation elongation factor 2 gene, GenBank Database accession number TC3544). The primers used for each analyzed gene are shown in Table 2.

All the analyses of gene transcript levels were conducted with quantitative PCR using an Mx3000P QPCR System (Agilent Technologies, USA). Means, standard errors (SE) and ANOVA analysis were performed using Statistica v4.0 (StatSoft, Inc.) software at a significance level of 0.05 .

\section{Phylogenetic analysis}

The nucleotide sequence of miR156/157 and miR172 and the deduced amino acid sequences of their target SPL and TOE genes from A. thaliana were used to find their orthologues in $P$. persica using a protein-protein BLAST from the following databases: miRBase (http://www.mirbase. org), Join Genome Institute (www.phytozome. org/peach) and GenBank (http://www.ncbi.nlm. nih.gov).

ClustalW was used to create multiple alignments in Bioedit software (http://www.mbio.ncsu.edu/ bioedit/bioedit.html). The resulting alignment was used to generate the phylogenetic tree by the neighbor joining method with MEGA software version 5.2 (http://www.megasoftware.net/).

\section{Results}

Identification of the aging gene pathway: miRs 156/157 and 172 and their putative targets in $P$. persica

To provide evidence of the homologous gene pathways related to vegetative phase change 
in $P$. persica, the sequences of the $A$. thaliana miR 156 and miR172 and their putative target $S P L$ and TOE genes were used to search for their orthologues in the peach genome from the International Peach Genome Initiative (www. phytozome.org/peach) using BLAST. We found that miR156 could be encoded by 9 (a-i) loci, while miR172 is encoded by 5 loci (a-e) (Figure $1)$, in agreement with the recent report of $\mathrm{Zhu}$ et al. (2012).

Figure 1 shows the high conservation in the mature sequences of miR 156/157 and miR172 families from $A$. thaliana and $P$. persica. In $A$. thaliana, miR156 and miR157 family members are encoded by the loci MIR156a-i and MIR157a$\mathrm{d}$, respectively. In peach, only the miR156 (a-i) isoforms have been described (Zhu et al., 2012), but some isoforms of miR157 in Arabidopsis have been misclassified as MIR156 loci in $P$. persica (Figure 1).
The miR172 family of Arabidopsis is encoded by the MIR172a-e loci. There are also five isoforms of this microRNA in P. persica, but some sequences are slightly different from those described in Arabidopsis (Zhu et al., 2012), (Figure 1B). In Arabidopsis, eight of the 17 genes that belong to the SPL family have been described as participating in vegetative phase change (Chen et al., 2010). In addition, six of the 144 members of the Arabidopsis AP2 family are involved in vegetative phase change and juvenile and adult development (TOE genes). Based on the previous report described by Xu et al. (2015) and BLAST, we identified six $S P L$-like and four TOE-like genes in P. persica, with homology to Arabidopsis SPL and TOE genes involved in vegetative phase change. At the amino acid level, the putative members belonging to the SPL family have similitude percentages ranging from 43.6 to $55.7 \%$, while the putative TOE proteins have amino acid similitude between 35.4 and $46.5 \%$

Table 2. List of primers used in this study.

\begin{tabular}{lc}
\hline Name & Sequence (5' $\left.{ }^{\prime}{ }^{\prime}\right)$ \\
\hline SPL_ppa012607-F & AAAGCAATACTATCGCCGCCATAAG \\
SPL_ppa012607-R & TCCGACGCCGCTCATTGTG \\
SPL_ppa022739-F & CCGCCGCCATAAGGTCTGTG \\
SPL_ppa022739-R & AGCCTTCTCCATAAGGTTCACCAG \\
SPL_ppa011968-F & GTTGTGCTTGTTTCTGGGCTGAG \\
SPL_ppa011968-R & ACGGAGTGCCTGTACCATTGC \\
SPL_ppa021582-F & GTTTCAAGGGAAATGAGGCTGGTAG \\
SPL_ppa021582-R & CTGCTGGTTGGTGGAGGAGTC \\
SPL_ppa005013-F & CAGGATTTTCATCGTGCTCTCTCTC \\
SPL_ppa005013-R & ATAGATGTTGAGTTTGCCAGTACCC \\
SPL_ppa007056-F & CCGATCACTCATGCTGGGACTG \\
SPL_ppa007056-R & GCTGCCTCCTGCTGCTCTG \\
TOE_ppa005230-F & AGAGCAACGGAAAAGAGAATGGATG \\
TOE_ppa005230-R & GGTGGTGGAGAATAGTTGTGTTAGG \\
TOE_ppa021782-F & AATGGAAAGAGGATGGAGCACAATG \\
TOE_ppa021782-R & TGCATTTGCCAAGCCCAGTTG \\
TOE_ppa003783-F & CCGCATCGGCAGTGATCTTTC \\
TOE_ppa003783-R & GCGTCTTGTGAGAGAGTGGAAAC \\
TOE_ppa018704-F & CCGAGATATACAAACTTGGCATGGC \\
TOE_ppa018704-R & CCGACGTTGTAGGAGGCAGAAG \\
\hline & \\
\hline
\end{tabular}


(Figures S1-S2). The multiple alignments of SPL-like proteins from peach and Arabidopsis revealed a high degree of conservation in the SBP domains (Figure S1). Similar results were reported by $\mathrm{Xu}$ et al. (2015) in $P$. mume, while the TOE-like proteins with their AP2 domains had the same behavior.

We analyzed the expression patterns of mature miR156/157 and miR172 and their putative target genes in leaves of Prunus sp. of different genotypes, ages and developmental phases, assuming high synteny and homology throughout the Prunus species for SPL and TOE genes.
The expression of miR 156/157 and miR172 and their targets genes in P. avium genotypes from seedling plants is age-dependent

As a first approach to ascertain the role of miR 156/157 and miR172 in stone fruit tree vegetative and reproductive transitions, their expression patterns were analyzed in $P$. avium genotypes from true seedling plants of different ages, both unflowered juvenile and flowered adult genotypes (Table 1).

The expression of miR156 and miR157 was higher in the juvenile one-year-old C15H14P20 and $\mathrm{C} 15 \mathrm{H} 16 \mathrm{P} 3 \mathrm{P}$. avium genotypes than in

\section{A}

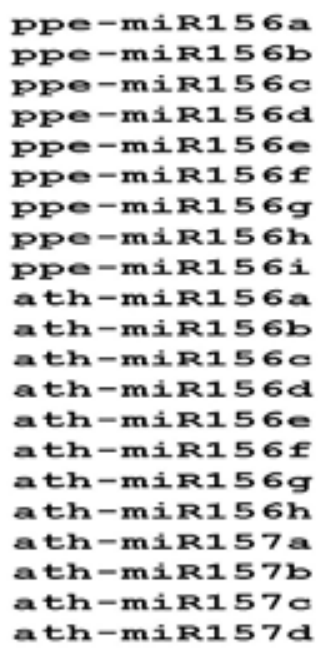

B

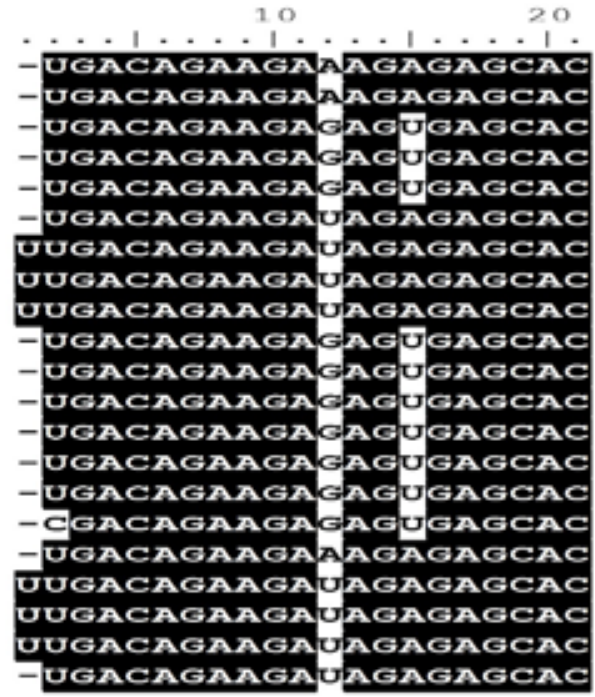

10 20

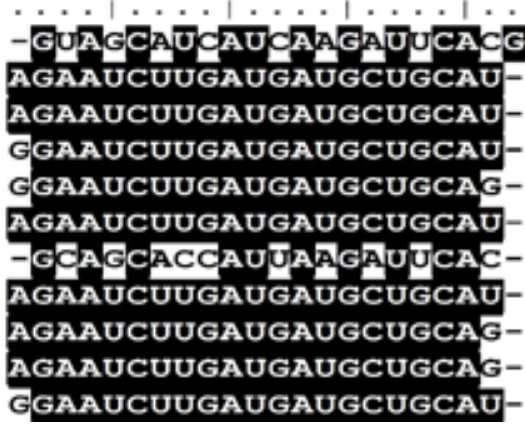

Figure 1. Alignment of mature sequences of Prunus persica miRNA156/157 and miRNA172 with homologues of Arabidopsis thaliana. A and B show the mature sequence of microRNAs $156 / 157$ and 172, respectively. Identical nucleotides among sequences are shaded in black. Multiple sequence alignment was performed by Clustal W using Bioedit software. 
the adult six-year-old C14H3P1 and C14H8P1 genotypes (Figure 2). The expression of miR172 was significantly higher in the older genotypes, C14H3P1 and C14H8P1, than in the younger ones, C15H14P20 and C15H16P3 (Figure 2).

Transcription profiles of the $S P L$ and TOE genes, which are targets of miR156/157 and miR172, respectively, were also evaluated. A lower expression of the $S P L$-like genes ppa022739 and ppa021582 was observed in the older sweet cherry genotypes, C14H3P1 and C14H8P1 (Figure $3 \mathrm{~B}$ and $\mathrm{E}$ ), while the expression of the other putative $S P L$ genes did not show significant differences associated with age (Figure $3 \mathrm{~A}, \mathrm{C}, \mathrm{D}$ and F). In the case of putative TOE genes, the expression of the gene ppa021782 was significantly lower in the adult genotypes (Figure $3 \mathrm{~J}$ ), while the expression of the other TOE genes did not show significant difference associated with age (Figure $3 \mathrm{G}, \mathrm{H}$ and I). In both groups of genes (SPL and TOE) that did not show a clear relationship with age, significant differences in the level of expression were associated with the genotype.

Expression of miRs $156 / 157$ and 172 and their target genes in Prunus sp. that were propagated in vitro

Transcriptional profiles of mature miRs 156, 157 and 172 and their target genes in four different Prunus sp., which had been propagated by in vitro methods, were analyzed in one-, two- and three-year-old plants. We characterized genotypes with short 'Garnem' and 'Mariana 2624' and long 'Colt' and 'Mazzard F12/1' juvenile phases belonging to the subgenera Amygdalus and Phrunophora, respectively.

The expression of miR156 was higher in two-year-old than in three-year-old plants, except the 'Mazzard F12' genotype, but the results stated that miR156 expression is not significant in all genotypes (Figure 4). The expression of miR157 was also higher in two-year-old plants than in three-year-old plants in all analyzed genotypes (Figure 4).
On the other hand, in the 'Mariana 2624', 'Garnem' and 'Mazzard F12/1' genotypes, the expression level of miR172 was lower in one-year-old plants than in two- and three-year-old plants (Figure 4), while in 'Colt', a late flowering genotype, miR172 expression was higher in one-year-old plants than in two- and three-year-olds (Figure 4).

In general, the expression patterns of putative $S P L$-like genes differed according to the genotype analyzed. In the 'Garnem' genotype, the expression of putative $S P L$ genes was lower in one-year-old plants than in three-year-old plants, with the exception of the gene ppa012607 (Figure 4). In the 'Mariana 2624' genotype, the expression of most putative SPL genes was higher in one-yearold plants than in older plants, with the exception of the $S P L$-like gene ppa005013, which does not significantly differ with the age of the plant and the SPL gene ppa007056, which has higher expression in two-year-old plants (Figure 4). In the 'Colt' genotype, the expression tendency of most putative $S P L$ genes analyzed (ppa012607, ppa011968, ppa005013 and ppa021582) was higher in three-year-old plants (Figure 4) when the levels of miR156 and miR157 were low (Figure 4). Finally, in the 'Mazzard F12/1' genotype, there were neither significant differences nor any clear tendency in the expression of most SPL genes among the plants of different ages (Figure 4).

Putative Prunus TOE gene expression (ppa003783, ppa005230, ppa021782 and ppa018704) exhibited different behaviors among the analyzed genotypes, although the 'Garnem' and 'Colt genotypes seem to share a tendency. The expression of at least three putative TOE genes was higher in threeyear-old plants (Figure 4). The exception was the TOE gene ppa003783, where its expression was not significantly different between the two ages in the 'Garnem' genotype. In the 'Mariana 2624' genotype, the expression of putative TOE genes ppa003783, ppa021782 and ppa005230 was higher in one-year-old plants (Figure 4), while in the 'Mazzard F12/1' genotype, the expression of three TOE genes (ppa018704, ppa005230 and 


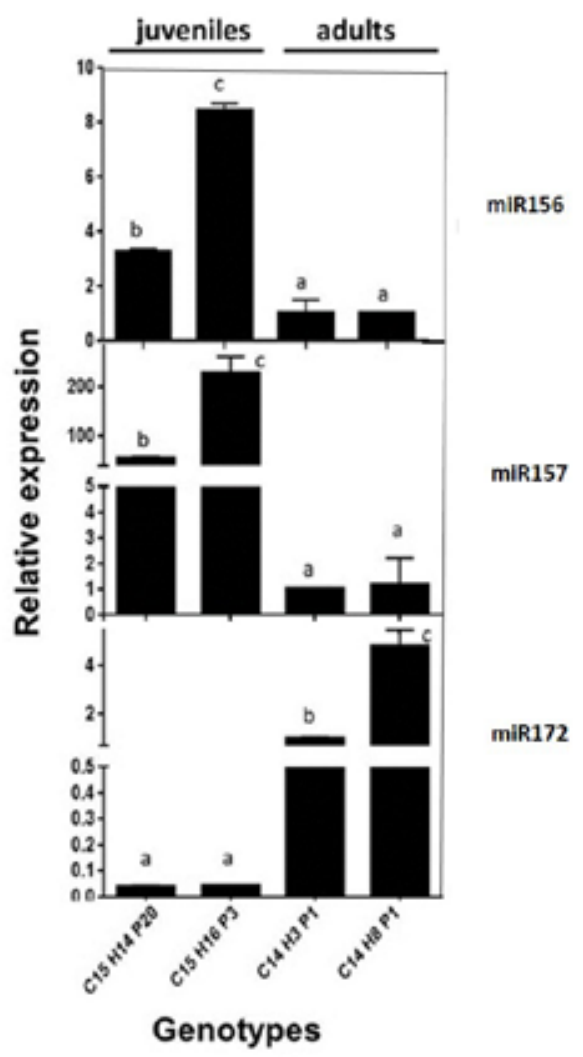

Figure 2. Expression profiles of mature microRNAs involved in developmental transitions in leaves of $P$. avium genotypes of different ages. Expression of mature microRNAs 156, 157 and 172 were examined by qRT-PCR using total RNA enriched in microRNAs and TaqMan ${ }^{\circledR}$ small RNA assays from leaves of one- $(\mathrm{C} 15 \mathrm{H} 14 \mathrm{P} 20$ and $\mathrm{C} 15 \mathrm{H} 16 \mathrm{P} 3)$ and six-year-old (C14H3P1 and C14H8P1) P. avium genotypes. Bars indicate mean relative expression values $+/$ - standard error $(n=3)$, normalized with a snoR41Y Taqman ${ }^{\circledR}$ small RNA control. The letters indicate significant differences.

ppa021782) was lower in three-year-old plants (Figure 4).

\section{Discussion}

Our results suggest that the role of the miR156/157miR172 module and their target genes is conserved in Prunus sp. members of the Rosaceae family. These microRNA families are the main players in vegetative and reproductive transitions, regulators of developmental timing, and they are evolutionarily conserved in both annual herbaceous plants and perennial trees (Bergonzi and Albani, 2011) (Figure 1). They are abundant with variable numbers of loci in Rosaceae plants (Barakat et al., 2012). We searched the homologous genes of the aging pathway, miRNAs 156/157 and 172 and their target genes in $P$. persica (Figure 1). Homologous genes of the aging pathway are found in the P. persica genome and are expressed in several Prunus species, suggesting that they play a role during developmental transitions in these perennial tree species (Xu et al., 2015). The target genes of miR156 are the $S P L$ genes that control aspects of plant growth and development, including vegetative phase change, flowering time, and the leaf initiation rate (Bergonzi and Albani, 2011). A bioinformatic analysis of putative cis- 


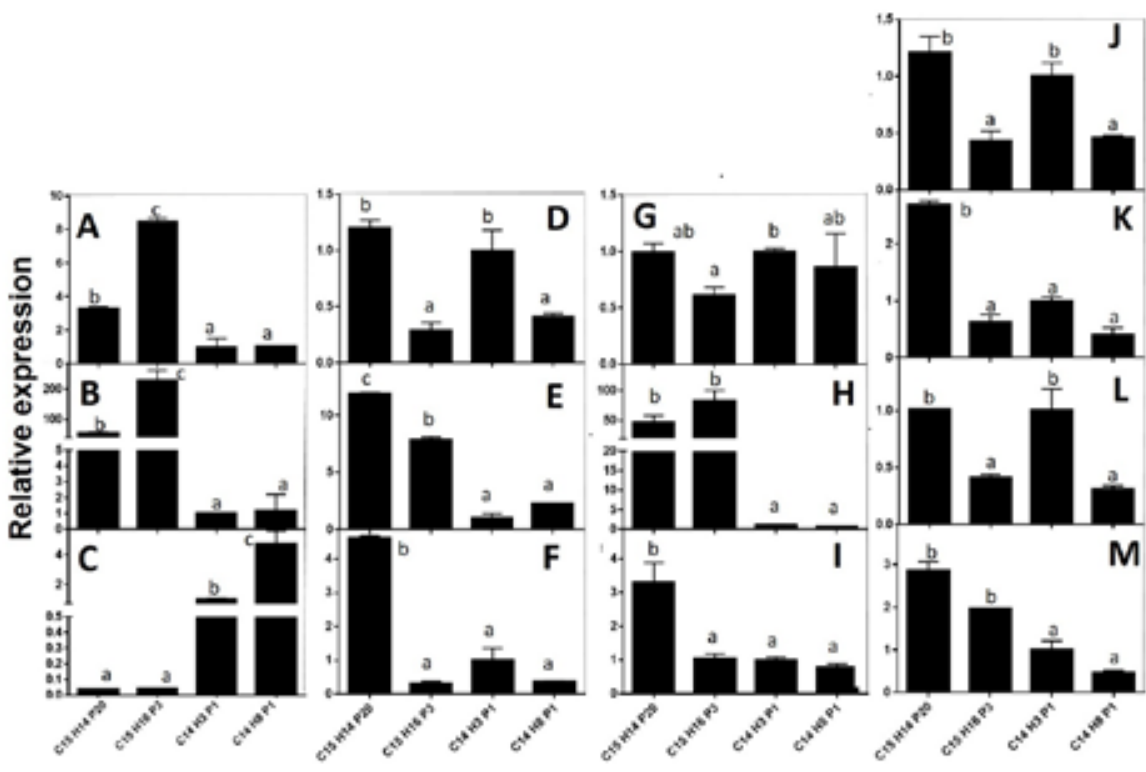

Genotypes

Figure 3. Expression profiles of $S P L$ and TOE-like genes in leaves of Prunus avium genotypes of different ages. Relative gene expression analyses were examined by qRT-PCR using total RNA from leaves of one-(C15H14P20 and C15H16P3) and six-year-old (C14H3P1 and C14H8P1) P. avium genotypes. A, B, C, D, E, and F are the expressions of the $S P L$ genes ppa012607, ppa022739, ppa007056, ppa011968, ppa021582, and ppa005013, respectively. G, H, I and J are the expressions of the TOE-like genes ppa003783, ppa018704, ppa005230 and ppa021782, respectively. Bars indicate mean relative expression values +/- standard error $(\mathrm{n}=3)$, normalized with TEF2 as a constitutive expressed gene. The letters indicate significant differences.

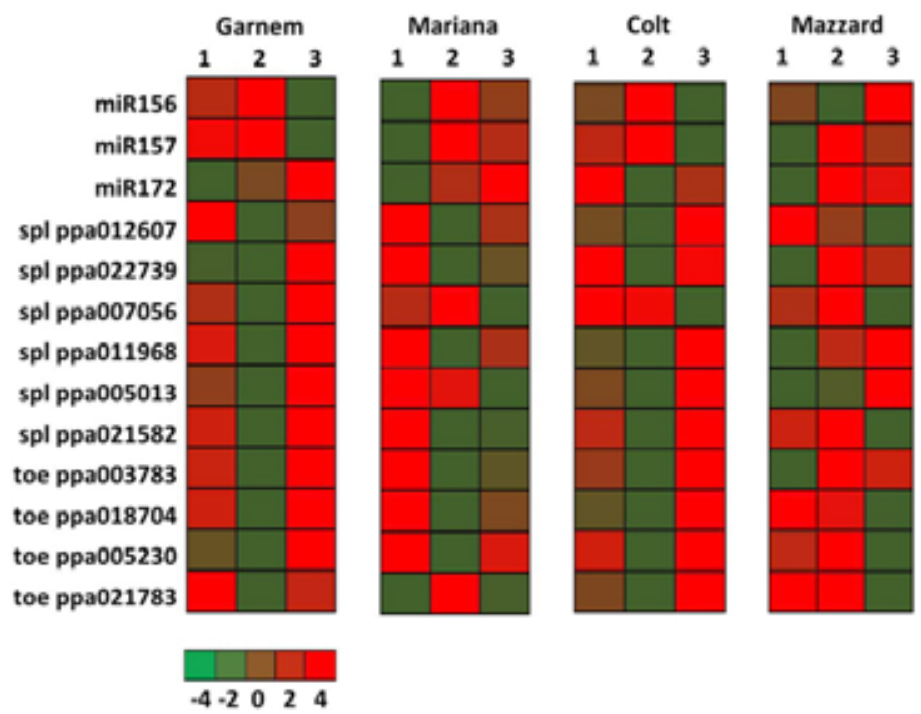

Figure 4. Expression profiles of aging gene pathway members in leaves of Prunus sp. of different ages. Heat map indicates the expression of microRNAs $156 / 157$ and 172 and their putative targets, SPL and TOE genes, respectively, in one-, two- and three-year-old plants of the Mariana ('Mariana 2624'), Garnem, Colt and Mazzard ('Mazzard F12/1') genotypes. Color changes represent the $\ln$ (mean) of the expression of every gene in all the genotypes. The heat map color scale was adjusted at intervals of -4 minimum (green) and 4 maximum (red). Graphs with standard errors can be seen in the supplementary Figure S3. 
regulatory elements in the promoter regions of PpSPLs and PpTOEs genes retrieved motifs that suggest their regulation by $\mathrm{N}$ metabolism, light, hormones and stress (Figure S4).

The expression profile of the miR156/157miR172 module and their target genes was determined in different Prunus sp. plants at different phases of maturity (juvenile and adult) and from different origins (from true seedlings and tissue culture micropropagated plants). The first group of true seedling plants included four $P$. avium genotypes, two juvenile and two adults, at one- and six-years-old, respectively. The expression profiles of miR156/ miR157 and miR172 were clearly associated with age (Figure 2). Transcription profiles of the SPL and TOE genes, which are targets of miR156/157 and miR172, respectively, were also evaluated. Contrary to what was expected, a low expression of the $S P L$ genes ppa022739 and ppa021582 was observed in the older sweet cherry genotypes, C14H3P1 and C14H8P1 (Figure $3 \mathrm{~B}$ and E), while the expression of the other putative $S P L$ genes did not show significant differences associated with the age of the analyzed genotypes (Figure $3 \mathrm{~A}, \mathrm{C}, \mathrm{D}$ and $\mathrm{F}$ ). In the case of putative TOE genes, as was expected, the expression of gene ppa021782 was significantly lower in the adult genotypes (Figure $3 \mathrm{~J}$ ), while the expression of the other TOE genes did not show significant difference associated with the age of the genotypes. In both groups of genes (SPL and TOE) that did not show a clear relation with age, significant differences in the level of expression were associated with the genotype effect. In addition, there are others regulators of these genes. For example, in Arabidopsis, under short day conditions, all three SPL genes are positively regulated by SUPPRESSION OF OVEREXPRESSION OF CONSTANS 1 (SOC1) through the gibberellin pathway. In contrast, under long day conditions, SOC1, FLOWERING LOCUS T (FT), and FLOWERING LOCUS D (FD) positively regulated AtSPL3, AtSPL4, and AtSPL5 in leaves in response to photoperiod signals (Jung et al., 2012).

The relationship between the flowering time and the adult phase in plants has been well described (Bergonzi and Albani, 2011). The expression of miR156 and miR172 in sweet cherry (Figure 2) correlates with observations in other species such as Arabidopsis, where miR156 expression is high in leaves during the juvenile phase and declines after the phase change, while miR172 expression has the opposite behavior (Wang et al., 2011; Wu et al., 2009). Our results suggest that in sweet cherry, the miRNA156/172 module plays a role in controlling juvenility and emerges as a candidate for developing strategies to shorten the juvenile phase in this economically important tree species. Its direct use as a potential biomarker of the adult phase in the management of breeding populations should be evaluated in large populations.

The expression of the miR156/miR172 module is affected not only by age but also by nutrients, stress and epigenetic factors, among others (Kim et al., 2015; Stief et al., 2014; Yu et al., 2013). However, we do not rule out that other miRNA families also have roles in developmental timing (Li et al., 2013; Xu et al., 2014).

Regarding the Prunus sp. from in vitro propagated plants, which include two known precocious genotypes, 'Garnem' and 'Mariana 2624', and two genotypes with longer juvenility, 'Colt' and 'Mazzard F12/1', the expression profiles were different for each genotype. Because all the genotypes were clonally propagated, age was the only factor that affected expression profiles. Therefore, a good correlation was expected between the age pathway model for both miRNA (miR156/157 and miR172) and their target genes. However, the expression profiles of these genes did not show clear tendencies. Our results suggest that 
the miR156/172 module in Prunus sp. plants from in vitro culture is deregulated (Figure 4). However, the accumulation of miR172 in in vitro derived plants seems to occur before that in seed derived plants. This level of accumulation would be different in each genotype (data not shown).

The specific relationships among members of the miR156/miR172 pathway can be complex. In the flowers of $P$. mume, the miR156 targets presented two opposite expression patterns. In contrast, the targets of miR172 were upregulated to different extents in the flowering stage (Wang et al., 2014). Different pathways participated in developmental transitions apart from the aging pathway. In Arabidopsis, SPL proteins positively regulated floral integrators and floral meristem identity genes (Wang et al., 2009; Wu et al., 2009). Other players are also involved in the miR156/miR172 module (Lal et al., 2011).

It is known that in vitro culture induces rejuvenation in woody species (Read and Bavougian, 2013), but it is not clear if this artificial method generates truly juvenile plants with reduced ontogenetic age or just plants with reduced physiological age (reinvigorated) by temporarily removing environmental and physiological constraints to growth. Our molecular analysis suggests that such plants do not have normal juvenile stages and/or transitions to adulthood, as do true seed plants. This supports the hypothesis that rejuvenated in vitro plants are reinvigorated plants with reduced physiological age. This may also explain the reason in vitro rejuvenated and micropropagated plants of mature origin may regain their real age after they are removed from the in vitro culture (Nas et al., 2003). The organogenesis in vitro system was used to micropropagate the Prunus sp. rootstock plants in this study (Agromillora S.A, personal communication), which means that buds of an adult plant were rejuvenated by tissue culture in special medium, thus avoiding callus formation and somatic embryogenesis. The latter is often associated with somaclonal variation, which is undesirable for micropropagation of valuable genotypes (Rodriguez-Enriquez et al., 2011).

The differential expression of miRNAs between conventional and micropropagated plants has been reported in strawberry, and during in vitro culture, miR156 was highly expressed and was inversely proportional to the expressions of its target gene SPL9 and miR172 ( $\mathrm{Li}$ et al., 2012). Additionally, there is evidence about the role of miR156 in redifferentiation during the induction of organogenesis (Liu et $a l ., 2014)$ and somatic embryo induction (Wu et al., 2011). Moreover, it is well documented that prolonged cultivation of plant cells in vitro induces single nucleotide substitutions and increases the global DNA methylation level in a time-dependent fashion, which is associated with aging in plants (Dubrovina and Kiselev, 2016).

These results demonstrate that the analysis of the expression of the aging gene pathway of miRNAs and its components are useful as molecular markers to study developmental transitions and rejuvenation of plants under in vitro culture or other treatments. In the future, these markers might help to understand the response of each genotype to different in vitro mediums and treatments and help to develop new protocols for propagating recalcitrant Prunus sp.

\section{Acknowledgements}

This work was funded by grants from the FONDECYT Postdoctoral Project 3120013 and FONDECYT Project 1121117 (Chile). PR was supported by grants from FONDECYT Postdoctoral Project 3140069. Some plant materials were kindly provided by Agromillora Sur S.A. 


\title{
Resumen
}

\begin{abstract}
A. Bastías, R. Almada, P. Rojas, J.M. Donoso, P. Hinrichsen y B. Sagredo. 2016. La vía génica del envejecimiento de los microARNs $156 / 157$ and 172 es alterada en plantas juveniles y adultas de Prunus sp. que provienen de propagación in vitro. Cien. Inv. Agr. 43(3):429-441. El cultivo in vitro es una técnica muy popular para propagar en masa genotipos de plantas valiosas, incluyendo cultivares de Prunus sp. Las plantas que se someten a procesos de cultivo de tejidos a menudo cambian su morfología y comportamiento debido a la "rejuvenilización" causada por los reguladores de crecimiento de planta incluidos en el medio. Para evaluar el efecto de la rejuvenilización por cultivo de tejido en Prunus sp, los patrones de expresión de la vía génica del envejecimiento descrita en plantas modelos, la cual incluye a las familias altamente conservadas de microRNAs (miR) 156/157 y miR172 y varios de sus genes blancos respectivos, fueron analizados en diferentes genotipos de Prunus sp. en fases de madurez distintas, incluyendo tanto plantas provenientes de semilla verdadera como micropropagadas mediante cultivo de tejidos. En los genotipos de plantas que provienen de semilla verdadera, la expresión de microR156 and miR157 fue más alta en hojas de plantas juveniles que en plantas adultas. El patrón opuesto fue observado con el patrón de expresión de miR172. Nuestros resultados sugieren que la vía génica del envejecimiento es conservada en Prunus y probablemente juega una función en el cambio de fase vegetativo. Sin embargo, plantas de Prunus sp. que fueron rejuvenecidas y propagadas por métodos in vitro mostraron un comportamiento más errático para los mi156 y miR157 y sus genes blancos, sugiriendo que el cultivo de tejidos altera el control normal de la vía del envejecimiento.
\end{abstract}

Palabras clave: cambio de fase, cultivo in vitro, desarrollo, rejuvenilización.

\section{References}

Alanagh, E.N., G.-a. Garoosi, R. Haddad, S. Maleki, M. Landín, and P.P. Gallego. 2014. Design of tissue culture media for efficient Prunus rootstock micropropagation using artificial intelligence models. Plant Cell, Tissue and Organ Culture (PCTOC) 117:349-359.

Aukerman, M.J., and H. Sakai. 2003. Regulation of flowering time and floral organ identity by a MicroRNA and its APETALA2 -Like target genes. The Plant Cell 15:2730-2741.

Barakat, A., A. Sriram, J. Park, T. Zhebentyayeva, D. Main, and A. Abbott. 2012. Genome wide identification of chilling responsive microRNAs in Prunus persica. BMC Genomics 13:481-492.

Bergonzi, S., and M.C. Albani. 2011. Reproductive competence from an annual and a perennial perspective. Journal of Experimental Botany 62:4415-4422.

Cardon, G., S. Hohmann, J. Klein, K. Nettesheim, H. Saedler, and P. Huijser. 1999. Molecular char- acterisation of the Arabidopsis SBP-box genes. Gene 237:91-104.

Chang, S., J. Puryear, and J. Cairney. 1993. A simple and efficient method for isolating RNA from pine trees. Plant Mol. Biol. Rep. 11:113-116.

Chen, X., Z. Zhang, D. Liu, K. Zhang, A. Li, and L. Mao. 2010. SQUAMOSA promoter-binding protein-like transcription factors: Star players for plant growth and development. Journal of Integrative Plant Biology 52:946-951.

Dubrovina, A.S., and K.V. Kiselev. 2016. Age-associated alterations in the somatic mutation and DNA methylation levels in plants. Plant Biology 18:185-196.

Jung, J.-H., P.J. Seo, S.K. Kang, and C.-M. Park. 2011. miR172 signals are incorporated into the miR156 signaling pathway at the SPL3/4/5 genes in Arabidopsis developmental transitions. Plant Molecular Biology 76:35-45.

Jung J.-H., Y. Ju, P.J. Seo, J.-H. Lee, and C.-M. Park. 2012. The SOC1-SPL module integrates photoperiod and gibberellic acid signals to control flowering time in Arabidopsis. Plant J. 69:577-588. 
Kim, J.-Y., J.E. Oh, Y.-S. Noh, and B. Noh. 2015. Epigenetic control of juvenile-to-adult phase transition by the Arabidopsis SAGA-like complex. The Plant Journal 83:537-545.

Lal, S., L.B. Pacis, and H.M.S. Smith. 2011. Regulation of the Squamosa Promoter-Binding ProteinLike genes/microRNA156 module by the homeodomain proteins Pennywise and Pound-Foolish in Arabidopsis. Molecular Plant 4:1123-1132.

Li, H., X. Zhao, H. Dai, W. Wu, W. Mao, and Z. Zhang. 2012. Tissue culture responsive MicroRNAs in strawberry. Plant Mol. Biol. Rep. 30:1047-1054.

Li, X., H. Bian, D. Song, S. Ma, N. Han, J. Wang, and M. Zhu. 2013. Flowering time control in ornamental gloxinia (Sinningia speciosa) by manipulation of miR159 expression. Annals of Botany 111:791-799.

Liu, W., W. Yu, L. Hou, X. Wang, F. Zheng, W. Wang, D. Liang, H. Yang, Y. Jin, and X. Xie. 2014. Analysis of miRNAs and their targets during adventitious shoot organogenesis of Acacia crassicarpa. PLoS ONE 9: e93438.

Read, P.E., and C.M. Bavougian. 2013. In vitro rejuvenation of woody species. Methods Mol Biol. 994:383-395.

Rodriguez-Enriquez, J., H.G. Dickinson, and R.T. Grant-Downton. 2011. MicroRNA misregulation: an overlooked factor generating somaclonal variation? Trends in Plant Science 16:242-248.

Stief, A., S. Altmann, K. Hoffmann, B.D. Pant, W.R. Scheible, and I. Bäurlea. 2014. Arabidopsis miR156 regulates tolerance to recurring environmental stress through SPL transcription factors. The Plant Cell 26:1792-1807.

von Aderkas, P., and J.M. Bonga. 2000. Influencing micropropagation and somatic embryogenesis in mature trees by manipulation of phase change, stress and culture environment. Tree Physiology 20:921-928.

Wang, J.-W., B. Czech, and D. Weigel. 2009. miR156-Regulated SPL transcription factors define an endogenous flowering pathway in Arabidopsis thaliana. Cell 138:738-749.

Wang, J.-W., M.Y. Park, L.-J. Wang, Y. Koo, X.-Y.
Chen, D. Weigel, and R.S. Poethig. 2011. MiRNA control of vegetative phase change in trees. PLoS Genetics 7: e1002012.

Wang, T., H. Pan, J. Wang, W. Yang, T. Cheng, and Q. Zhang. 2014. Identification and profiling of novel and conserved microRNAs during the flower opening process in Prunus mume via deep sequencing. Molecular Genetics and Genomics 289:169-183.

Wendling, I., S.J. Trueman, and A. Xavier. 2014. Maturation and related aspects in clonal forestry-part II: reinvigoration, rejuvenation and juvenility maintenance. New Forests 45:473-486.

Wu, G., M.Y. Park, S.R. Conway, J.-W. Wang, D. Weigel, and R.S. Poethig. 2009. The sequential action of miR156 and miR172 regulates developmental timing in Arabidopsis. Cell 138:750759.

Wu, X.M., M.Y. Liu, X.X. Ge, Q. Xu, and W.W., Guo. 2011. Stage and tissue-specific modulation of ten conserved miRNAs and their targets during somatic embryogenesis of Valencia sweet orange. Planta 233:495-505.

Xu, M.Y., L. Zhang, W.W. Li, X.L. Hu, M.-B. Wang, Y.L. Fan, C.Y. Zhang, and L. Wang. 2014. Stress-induced early flowering is mediated by miR169 in Arabidopsis thaliana. J. Exp. Bot. 65:89-101.

Xu, Z., L. Sun, Y. Zhou, W. Yang, T. Cheng, J. Wang, and Q. Zhang. 2015. Identification and expression analysis of the Squamosa promoter-binding protein (SBP)-box gene family in Prunus mume. Mol Genet Genomics 290:1701-1715.

Yu, S., L. Cao, C.-M. Zhou, T.-Q. Zhang, H. Lian, Y. Sun, J. Wu, J. Huang, G. Wang, and J. Wang. 2013. Sugar is an endogenous cue for juvenileto-adult phase transition in plants. eLife 2: e00269.

Zhu, H., R. Xia, B. Zhao, Y.-q. An, C.D. Dardick, A.M. Callahan, and Z. Liu. 2012. Unique expression, processing regulation, and regulatory network of peach (Prunus persica) miRNAs. BMC Molecular Biology 12:149-167. 